\title{
A case of autosplenectomy associated with T-cell checkpoint inhibitor treatment
}

Rachel Delahunty, ${ }_{1}^{1}$ Margaret Lee, ${ }^{1}$ Mineesh Datta, ${ }^{2}$ Phillip Parente ${ }^{1,3}$

1 Department of Medical Oncology, Eastern Health, Melbourne, Victoria, Australia ${ }^{2}$ Medical Imaging, Eastern Health, Melbourne, Victoria, Australia

${ }^{3}$ Eastern Clinical Research Unit, Monash University, Melbourne, Australia

\section{Correspondence to} Dr Rachel Delahunty, rachel.delahunty3@ easternhealth.org.au

Accepted 12 September 2017

\section{DESCRIPTION}

A 77-year-old Caucasian man presented to the oncology service with de novo v-raf murine sarcoma viral oncogene homolog B (BRAF), wild-type metastatic melanoma and widespread disease involving; subcutaneous fat, lymph nodes, bone and spleen with no history of autoimmunity. At diagnosis, the spleen was measured within normal limits on CT. In November 2013, he commenced treatment on a phase-III randomised double-blinded clinical trial (CA209-067) and received combination checkpoint inhibitor therapy with ipilimumab and nivolumab.

Radiological mixed response was observed after threemonths, with a partial response in all target lesions (RECIST V.1.1 criteria) but an increase in the size of the non-target splenic metastasis consistent with pseudoprogression. In conjunction, splenic enlargement was demonstrated (figure 1).

After seven months of immunotherapy, he achieved a complete radiological response to treatment with an accompanying reduction in splenic size (figure 2). Subsequent imaging demonstrated a persistent reduction in splenic size and by June 2015, only a spleen remnant remained (figure 3). Functional hyposplenism was demonstrated with Howell-Jolly bodies and Acanthocytes on the peripheral blood film (figure 4).

His treatment was complicated by a range of immune-related adverse events (irAE) including hypophysitis, nephritis and colitis.Although steroid dependant, he remains in radiological remission with an excellent performance status. In the absence of alternative autoimmune pathology, we hypothesise that this is a case of checkpoint inhibitor-induced autosplenectomy, the first reported case of a new rare irAE.

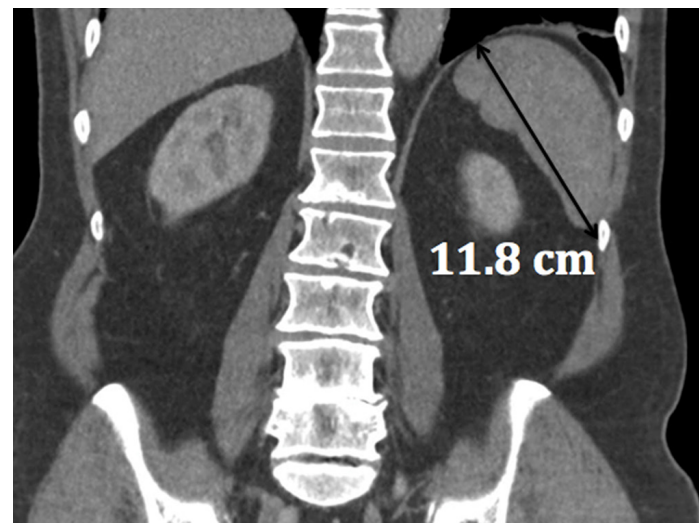

Figure 1 Subsequent restaging coronal abdominopelvic CT demonstrating an increased splenic length of $11.8 \mathrm{~cm}$.

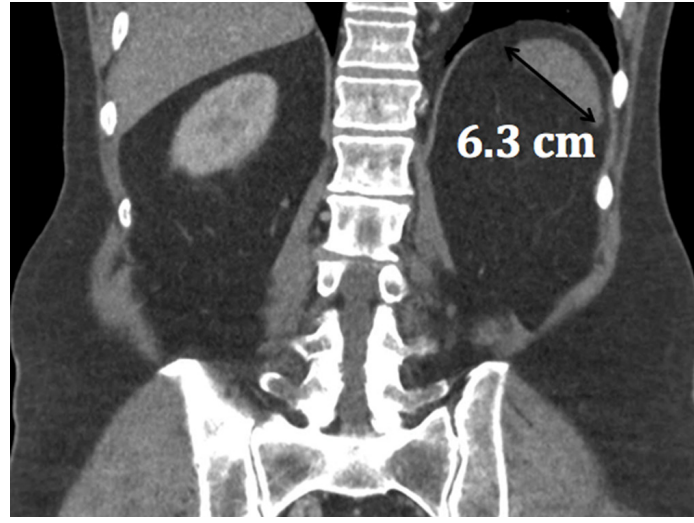

Figure 2 Coronal abdominopelvic CT demonstrating a reduction in the splenic length to $6.3 \mathrm{~cm}$.

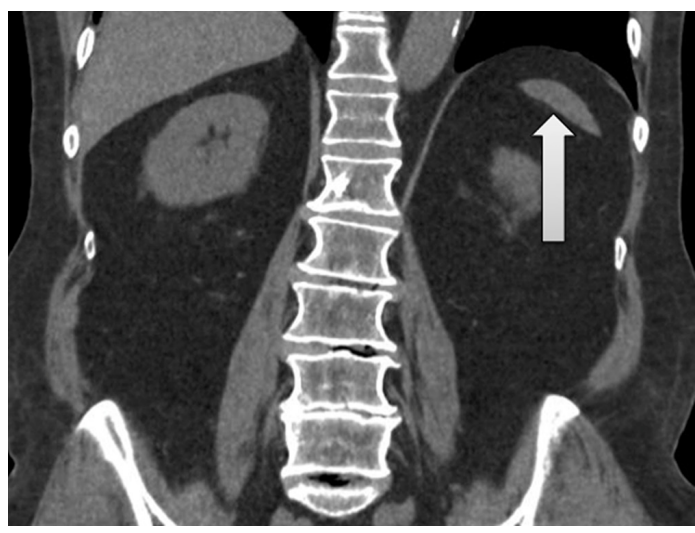

Figure 3 Coronal abdominopelvic CT with residual splenic remnant.

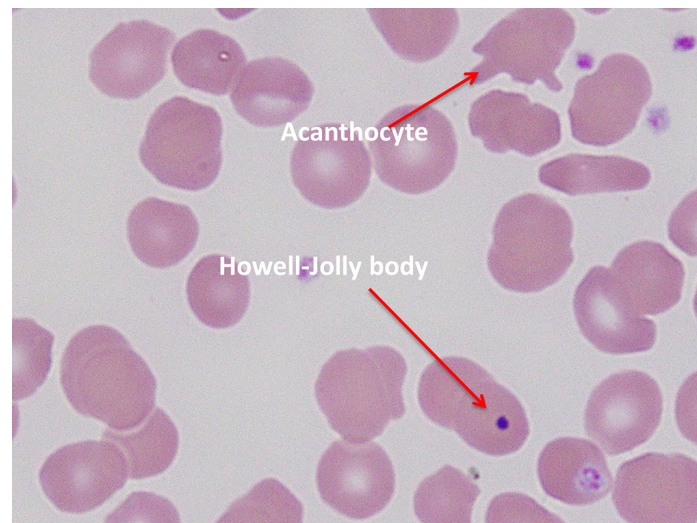

Figure 4 Blood film demonstrating signs of hyposplenism with Acanthocytes and Howell-Jolly bodies.

With increasing use of checkpoint inhibitor's in oncology, clinical vigilance for rare irAE associated with these agents is required. 


\section{Learning points}

- Checkpoint inhibitors are a form of immunotherapy that have revolutionised the management of melanoma and provide benefit across a spectrum of malignancies.

- These new agents bring with them unique immune-related adverse events (irAE).

- Adverse events associtaed with checkpoint inhibitors are common, particularly with combination therapy (55\% grade 3-4 severity ${ }^{1}$ ) and can be potentially fatal.

- Rare immune-related adverse events are increasingly being recognised, they can be inflammatory or autoimmune and impact almost any organ.

- As checkpoint inhibitors become part of routine clinic practice, it is paramount that all clinicians providing primary and supportive care to oncology patients develop knowledge and experience with these agents and their potential toxicities.
Acknowledgements Thanks to Dr Marija Borosak and Dr Rachel Wong for their contribution.

Contributors $\mathrm{RD}$ and $\mathrm{ML}$ contributed to the acquisition, analysis and interpretation of data for the report, as well as drafting the manuscript. MD contributed to the conception of the manuscript including analysis of the images for the case report and contributed to the development of the manuscript. PP contributed to the development of the concept and the design and development of the manuscript. All authors contributed to critical appraisal and revision of the work and approved the final version of the manuscript for publication. Additionally, all authors agree to be accountable for the accuracy and integrity of the final manuscript approved.

Competing interests None declared.

Patient consent Obtained.

Provenance and peer review Not commissioned; externally peer reviewed.

(c) BMJ Publishing Group Ltd (unless otherwise stated in the text of the article) 2017. All rights reserved. No commercial use is permitted unless otherwise expressly granted.

\section{REFERENCE}

1 Larkin J, Chiarion-Sileni V, Gonzalez R, et al. Combined nivolumab and ipilimumab or monotherapy in untreated melanoma. N Engl J Med 2015;373:23-34.

Copyright 2017 BMJ Publishing Group. All rights reserved. For permission to reuse any of this content visit http://group.bmj.com/group/rights-licensing/permissions.

BMJ Case Report Fellows may re-use this article for personal use and teaching without any further permission.

Become a Fellow of BMJ Case Reports today and you can:

- Submit as many cases as you like

- Enjoy fast sympathetic peer review and rapid publication of accepted articles

- Access all the published articles

Re-use any of the published material for personal use and teaching without further permission

For information on Institutional Fellowships contact consortiasales@bmjgroup.com

Visit casereports.bmj.com for more articles like this and to become a Fellow 